\title{
SKIN-FOLD THICKNESS IN THE AGED MEASUREMENTS IN A SAMPLE OF THE LONDON POPULATION
}

BY

OTTO APPENZELLER

Institute of Neurology, National Hospital, London

Corpulence was once looked upon as a sign of well-being and social success. The effect of obesity on longevity was, however, already suspect in 1813. William Wadd (1813), in his book "Cursory Remarks on Corpulency", states: "If the increase of wealth and the refinements of modern times have tended to banish plague and pestilence from our cities, they have probably introduced the whole train of nervous disorders and increased the frequency of corpulence".

It was not until the figures of the Connecticut Mutual Life Insurance Co. (1912) on the relation of excess weight and increased mortality had been published, that the term overweight became frequently used, so much so that on occasions it has replaced careful examination and diagnostic endeavour.

That weight is a poor measure of the amount of adipose tissue particularly in the aged has been shown by Brozek and Keys (1950). Old men have a higher fat content than young men at the same relative weight, that is, the percentage of the standard reference weight (Life Insurance Tables) for the man's age and height.

Validation of the various indirect methods for measurement of the amount of adipose tissue in man has been carried out by Brozek and Keys (1951). The highest correlation was found between chest skin-fold thickness and total body fat as measured by specific gravity.

The tendency to relate many degenerative conditions of the vascular system to obesity has often resulted in conflicting statements. For example, Weiss and Minot (1933) stated that there was no convincing evidence that overnutrition led to atherosclerosis in man. Wilens (1947), on the other hand, stated that obesity increased progressively with age, that there was a direct relation between overnutrition and atherosclerosis, and that this was independent of age, sex, diabetes, heart weight, or hypertension. One of the reasons for this divergence of opinion is the different standards and methods used to measure fatness. There is therefore a need for norms of adiposity, particularly in old age, at a time when so many conditions are being frequently related, if not directly attributed, to obesity.

This paper reports skin-fold measurements on $\mathbf{2 7 2}$ symptom-free middle-aged and old people carried out in the course of an investigation on the incidence and effect of obesity in chronic cerebral vascular disease (Appenzeller, 1962).

The measurements were obtained from London Transport employees who presented themselves for annual medical review or from applicants for employment at the time of their chest $x$-ray examination. In addition healthy ambulant inmates of a home for the aged were measured. These comprised all the "65 and over" age group and were mostly females.

\section{METHOD}

The Harpenden skin-fold caliper was used (Edwards, Hammond, Healy, Tanner, and Whitehouse, 1955), and all measurements were performed by the author. The sites were:

(1) Triceps.-Half way down the left arm between the tip of the acromion and the head of the radius, with the fold in a line passing up the arm from the tip of the olecranon process.

(2) Subscapular.-Just below the angle of the left scapula, the fold parallel to the natural cleavage line of the skin.

(3) Supra-iliac.-Dust above the left iliac crest in the mid-axillary line, the fold also parallel to the cleavage line of the skin. 
The folds were picked up with the left thumb and index finger. A sufficient amount of skin was pinched up to allow a full fold to be held clear away from the underlying tissues during the application of the caliper.

The figures obtained were transformed using the formula-skin-fold transform $=100 \log 10$ (skin fold in $0.1 \mathrm{~mm}$.-18). This transformation is necessary because the frequency distribution of the measurements is always markedly skew to the right, and the error of the readings is proportional to the absolute values registered with the caliper (Edwards and others, 1955).

\section{RESULTS}

The group measured consisted of 157 males and 115 females. The males were between 35 and 88 years old, females between 35 and 94 .

Table I gives the number of persons in each group and the mean and standard deviation (in $\mathrm{mm}$.) of the skin-fold measurements obtained.

The percentage of sedentary and manual workers is given in Table II. Clerks and drivers were classified as "sedentary"; all others, including pensioners who had done labouring in the past and housewives, as "manual workers". Males still engaged in sedentary occupations had thicker skin folds than manual workers. This difference was less marked when labourers who had retired more than one year before the measurement were compared with retired "sedentary" subjects.

\section{TABLE II}

PERCENTAGE OF MANUAL AND SEDENTARY WORKERS IN 272 SUBJECTS, BY AGE

\begin{tabular}{c|c|c|c|c}
\hline \multirow{2}{*}{$\begin{array}{c}\text { Age } \\
\text { Group }\end{array}$} & \multicolumn{2}{|c|}{ Males } & \multicolumn{2}{c}{ Females } \\
\cline { 2 - 4 } & Manual & Sedentary & Manual & Sedentary \\
\hline $35-44$ & 60 & 40 & 59 & 41 \\
\hline $45-54$ & 61 & 39 & 50 & 50 \\
\hline $55-64$ & 53 & 47 & 100 & - \\
\hline $65+$ & 94 & 6 & 100 & - \\
\hline
\end{tabular}

The Figure (opposite) shows the transformed 10th, 25th, 75th, and 90th percentiles for the triceps, subscapular, and supra-iliac measurements.

Table III gives the transformed figures.

TABLE I

MEAN AND STANDARD DEVIATION OF SKIN-FOLD THICKNESS (IN MM.), BY AGE AND SEX IN A SAMPLE of 157 MEN AND 115 WOMEN

\begin{tabular}{|c|c|c|c|c|c|c|c|c|}
\hline \multirow{3}{*}{$\underset{\text { (yrs) }}{\text { Age Group }}$} & \multicolumn{4}{|c|}{ Males } & \multicolumn{4}{|c|}{ Females } \\
\hline & \multirow{2}{*}{$\begin{array}{l}\text { No. of } \\
\text { Subjects }\end{array}$} & Triceps & Subscapular & Supra-Iliac & \multirow{2}{*}{$\begin{array}{l}\text { No. of } \\
\text { Subjects }\end{array}$} & Triceps & Subscapular & Supra-Iliac \\
\hline & & Mean \pm S.D. & Mean \pm S.D. & Mean \pm S.D. & & Mean \pm S.D. & Mean $t$ S.D. & Mean \pm S.D. \\
\hline $35-44$ & 43 & $9 \cdot 2 \pm 4 \cdot 2$ & $14.6 \pm 7 \cdot 6$ & $11 \cdot 9 \pm 8 \cdot 6$ & 17 & $20.4 \pm 7.9$ & $17 \cdot 4 \pm 8 \cdot 7$ & $17 \cdot 6 \pm 10 \cdot 1$ \\
\hline $45-54$ & 33 & $8 \cdot 9 \pm 3 \cdot 3$ & $14 \cdot 7 \pm 4 \cdot 7$ & $13 \cdot 2 \pm 7 \cdot 9$ & 14 & $21 \cdot 7 \pm 7 \cdot 6$ & $21 \cdot 8 \pm 10 \cdot 4$ & $19 \cdot 4 \pm 11 \cdot 0$ \\
\hline $55-64$ & 30 & $9 \cdot 7 \pm 3 \cdot 0$ & $15 \cdot 4 \pm 5 \cdot 3$ & $13 \cdot 0 \pm 7 \cdot 9$ & 9 & $21 \cdot 0 \pm 9 \cdot 7$ & $20 \cdot 5 \pm 9 \cdot 4$ & $21 \cdot 8+8.6$ \\
\hline $65+$ & 51 & $8 \cdot 2 \pm 3 \cdot 5$ & $11 \cdot 4 \pm 4 \cdot 3$ & $11 \cdot 2 \pm 6 \cdot 7$ & 75 & $18 \cdot 5+8 \cdot 8$ & $18 \cdot 8 \pm 10 \cdot 1$ & $20 \cdot 6 \pm 11 \cdot 1$ \\
\hline
\end{tabular}

TABLE III

PERCENTILES OF TRANSFORMED TRICEPS, SUBSCAPULAR, AND SUPRA-ILIAC SKIN-FOLD MEASUREMENTS, BY AGE AND SEX

\begin{tabular}{|c|c|c|c|c|c|c|c|c|c|c|c|c|c|}
\hline \multirow{2}{*}{ Sex } & \multirow{2}{*}{ Percentile } & \multicolumn{4}{|c|}{ Triceps } & \multicolumn{4}{|c|}{ Subscapular } & \multicolumn{4}{|c|}{ Supra-Iliac } \\
\hline & & $35-44$ & $45-54$ & $55-64$ & $65+$ & $35-44$ & $45-54$ & $55-64$ & $65+$ & $35-44$ & $45-54$ & $55-64$ & $65+$ \\
\hline Male . . & $\begin{array}{l}\text { 10th } \\
25 \text { th } \\
50 \text { th } \\
75 \text { th } \\
90 \text { th }\end{array}$ & $\begin{array}{l}144 \\
162 \\
178 \\
202 \\
214\end{array}$ & $\begin{array}{l}158 \\
176 \\
186 \\
196 \\
200\end{array}$ & $\begin{array}{l}164 \\
180 \\
188 \\
198 \\
204\end{array}$ & $\begin{array}{l}144 \\
160 \\
174 \\
186 \\
202\end{array}$ & $\begin{array}{l}174 \\
180 \\
202 \\
224 \\
238\end{array}$ & $\begin{array}{l}182 \\
198 \\
210 \\
224 \\
228\end{array}$ & $\begin{array}{l}186 \\
198 \\
210 \\
226 \\
230\end{array}$ & $\begin{array}{l}176 \\
180 \\
198 \\
206 \\
214\end{array}$ & $\begin{array}{l}136 \\
152 \\
182 \\
212 \\
236\end{array}$ & $\begin{array}{l}148 \\
166 \\
202 \\
218 \\
230\end{array}$ & $\begin{array}{l}148 \\
174 \\
198 \\
226 \\
240\end{array}$ & $\begin{array}{l}152 \\
168 \\
182 \\
212 \\
226\end{array}$ \\
\hline Female & $\begin{array}{l}\text { 10th } \\
25 \text { th } \\
50 \text { th } \\
\text { 75th } \\
90 \text { th }\end{array}$ & $\begin{array}{l}186 \\
212 \\
224 \\
234 \\
244\end{array}$ & $\begin{array}{l}202 \\
216 \\
224 \\
240 \\
250\end{array}$ & $\begin{array}{l}176 \\
200 \\
230 \\
240 \\
248\end{array}$ & $\begin{array}{l}182 \\
204 \\
218 \\
232 \\
246\end{array}$ & $\begin{array}{l}186 \\
194 \\
212 \\
228 \\
250\end{array}$ & $\begin{array}{l}194 \\
202 \\
236 \\
240 \\
248\end{array}$ & $\begin{array}{l}166 \\
198 \\
218 \\
244 \\
246\end{array}$ & $\begin{array}{l}178 \\
196 \\
218 \\
236 \\
252\end{array}$ & $\begin{array}{l}156 \\
192 \\
210 \\
238 \\
248\end{array}$ & $\begin{array}{l}166 \\
204 \\
218 \\
240 \\
252\end{array}$ & $\begin{array}{l}148 \\
224 \\
236 \\
242 \\
246\end{array}$ & $\begin{array}{l}156 \\
196 \\
228 \\
242 \\
254\end{array}$ \\
\hline
\end{tabular}



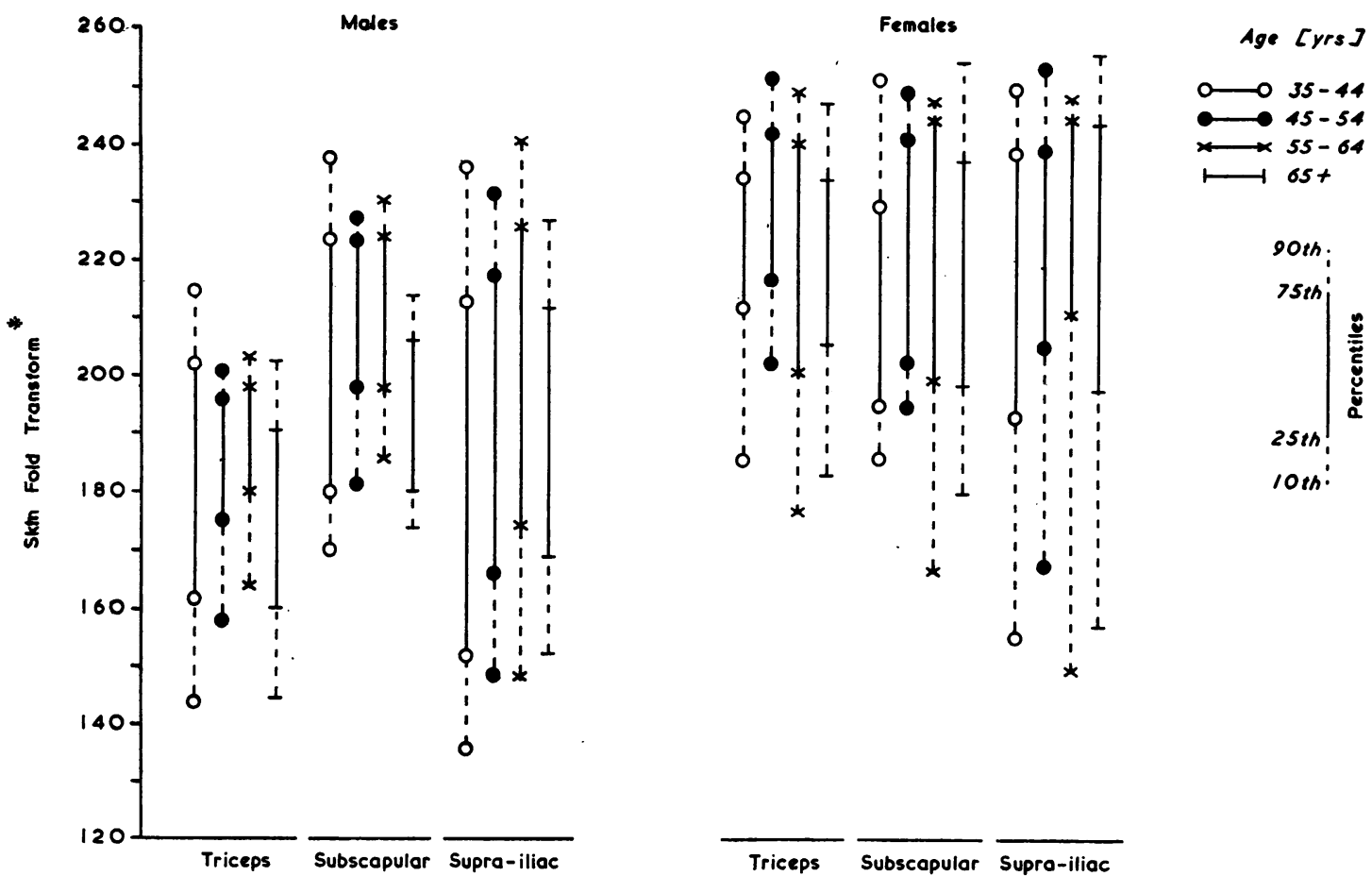

FIgURE.-Transformed skin-fold measurements. Percentiles of triceps, subscapular, and supra-iliac measurements in 272 subjects, by age and sex.

Table IV the actual values (in $\mathrm{mm}$.) before transformation. Females in all age groups had thicker skin folds than males at the three sites measured.

\section{Discussion}

Skin-fold thickness is a good indirect measure of obesity (Tanner, 1959). It is surprising therefore that no norms are available for the older age groups.
This is partly due to the use of varying types of calipers which makes the pooling of results impossible, and partly to the difficulty in accumulating a large enough number of elderly symptom-free subjects for measurement.

The only data available on skin-fold thickness of old people are those of Pett and Ogilvie (1956). These were obtained from Canadians by a number of observers and with a slightly different type of

TABLE IV

PERCENTILES OF TRICEPS, SUBSCAPULAR, AND SUPRA-ILIAC SKIN-FOLD MEASUREMENTS (IN MM.) BEFORE TRANSFORMATION, BY AGE AND SEX

\begin{tabular}{|c|c|c|c|c|c|c|c|c|c|c|c|c|c|}
\hline \multirow{2}{*}{ Sex } & \multirow{2}{*}{ Percentile } & \multicolumn{4}{|c|}{ Triceps } & \multicolumn{4}{|c|}{ Subscapular } & \multicolumn{4}{|c|}{ Supra-Iliac } \\
\hline & & $35-44$ & $45-54$ & $55-64$ & $65+$ & $35-44$ & $45-54$ & $55-64$ & $65+$ & $35-44$ & $45-54$ & $55-64$ & $65+$ \\
\hline Male & $\begin{array}{l}10 \text { th } \\
25 \text { th } \\
50 \text { th } \\
75 \text { th } \\
90 \text { th }\end{array}$ & $\begin{array}{r}4.5 \\
6.0 \\
9.0 \\
13.5 \\
17.0\end{array}$ & $\begin{array}{r}6 \cdot 0 \\
7.5 \\
8.0 \\
10.5 \\
12.0\end{array}$ & $\begin{array}{r}6 \cdot 5 \\
7 \cdot 5 \\
8 \cdot 5 \\
10 \cdot 5 \\
11 \cdot 5\end{array}$ & $\begin{array}{r}4.5 \\
6.0 \\
7.5 \\
10.0 \\
15.5\end{array}$ & $\begin{array}{r}7.0 \\
8.5 \\
12.5 \\
19.0 \\
26.5\end{array}$ & $\begin{array}{r}8.5 \\
11.0 \\
14.5 \\
19.0 \\
21.0\end{array}$ & $\begin{array}{r}9.5 \\
11.0 \\
13.5 \\
17.5 \\
21.0\end{array}$ & $\begin{array}{r}7.0 \\
8.5 \\
10.0 \\
13.5 \\
16.0\end{array}$ & $\begin{array}{r}4 \cdot 0 \\
5.5 \\
8.5 \\
14.0 \\
25.0\end{array}$ & $\begin{array}{r}5 \cdot 0 \\
6 \cdot 5 \\
12.0 \\
17 \cdot 5 \\
22.0\end{array}$ & $\begin{array}{r}5 \cdot 0 \\
6 \cdot 5 \\
9 \cdot 5 \\
18 \cdot 5 \\
24 \cdot 0\end{array}$ & $\begin{array}{r}5 \cdot 5 \\
7 \cdot 0 \\
9 \cdot 0 \\
15 \cdot 5 \\
20 \cdot 5\end{array}$ \\
\hline Female & $\begin{array}{l}\text { 10th } \\
25 \text { th } \\
50 \text { th } \\
\text { 75th } \\
90 \text { th }\end{array}$ & $\begin{array}{r}9.5 \\
12.5 \\
19.5 \\
24.5 \\
29.0\end{array}$ & $\begin{array}{r}9.5 \\
17.0 \\
19.0 \\
25.0 \\
33.5\end{array}$ & $\begin{array}{r}8 \cdot 0 \\
9 \cdot 0 \\
22 \cdot 0 \\
28 \cdot 0 \\
32 \cdot 5\end{array}$ & $\begin{array}{r}8 \cdot 0 \\
13.0 \\
17.5 \\
22.0 \\
30.5\end{array}$ & $\begin{array}{r}9.5 \\
10.5 \\
15.0 \\
21.5 \\
30.5\end{array}$ & $\begin{array}{r}9.5 \\
11.0 \\
20.0 \\
26.0 \\
32.0\end{array}$ & $\begin{array}{r}6.5 \\
11.5 \\
17.0 \\
29.5 \\
31.5\end{array}$ & $\begin{array}{r}7 \cdot 5 \\
11.0 \\
16 \cdot 5 \\
24.5 \\
35.5\end{array}$ & $\begin{array}{r}5.5 \\
7.5 \\
14.5 \\
26.5 \\
31.0\end{array}$ & $\begin{array}{r}6.0 \\
11.5 \\
17.5 \\
22.5 \\
35.5\end{array}$ & $\begin{array}{r}5.0 \\
10.5 \\
24.0 \\
28.0 \\
31.0\end{array}$ & $\begin{array}{r}5 \cdot 5 \\
11 \cdot 5 \\
21 \cdot 0 \\
29 \cdot 0 \\
35 \cdot 5\end{array}$ \\
\hline
\end{tabular}


caliper, and are therefore not strictly comparable to the figures presented here. Moreover, no transformation to a logarithmic scale was used and only the triceps folds were measured. The values obtained are slightly lower than the measurements reported here.

The recognition of the Harpenden caliper as the best instrument (Tanner, 1959) and the standardization of sites and method of measurement, should allow pooling of results. The 157 males and 115 females whose skin-fold thickness is reported here are "normals", i.e. they were either employed and free from symptoms of disease or were living because of age in an institution, but were ambulant and not requiring medical attention. It is of course likely that, particularly in the older age groups, subclinical degenerative conditions of the vascular and other systems were present, but these may be taken as "normal" accompaniments of ageing. Though not producing symptoms at the time of the skin-fold measurement they could no doubt have been detected by pathological examination.

It can be argued that the measurements reported here came from a highly selected group. However, different occupations were represented and, although some bias was present because of the income group in this sample, the amount of activity and the number of calories taken could not have differed greatly from those of the rest of the London population of corresponding age.

It is, however, not warranted to make an internal comparison of measurements between the four age groups because the "65 and over" were no longer engaged in productive work and their level of physical activity must have been different from that of the younger groups.

Although it should be stressed that these data cannot be taken as representative of the London population, they nevertheless provide a basis for further measurements and may serve as a standard for comparison with values obtained from similar samples from other populations.

\section{SUMMARY}

(1) Skin-fold thickness was measured in 272 persons.

(2) The figures represent the skin-fold values in a symptom-free sample of the London population as measured with the Harpenden caliper.

(3) Measurements were made at the left triceps, subscapular, and supra-iliac sites.

My thanks are due to Dr. John Marshall, Reader in Clinical Neurology, University of London, for advice and encouragement. I wish also to acknowledge the help received from Dr. L. G. Norman and Dr. J. L. Fyfe of the London Transport Authority and from the Matron of Luxborough Lodge, London.

This work was done while in receipt of a Travelling Scholarship in Medicine of the Royal Australasian College of Physicians and of a grant in aid from the Postgraduate Committee in Medicine, the University of Sydney.

\section{REFERENCES}

Appenzeller, O. (1962). "Obesity in Chronic Cerebro Vascular Disease". In preparation.

Brozek, J., and Keys, A. (1950). Science, 112, 788.

- - (1951). Brit. J. Nutr., 5, 194.

Connecticut Mutual Life Insurance Co. (1912).

Edwards, D. A. W., Hammond, W. H., Healy, M. J. R., Tanner, J. M., and Whitehouse, R. H. (1955). Brit. J. Nutr., 9, 133.

Pett, L. B., and Ogilvie, G. F. (1956). Hum. Biol., 28, 177.

Tanner, J. M. (1959). Proc. Nutr. Soc. (Lond.), 18, 148.

Wadd, W. (1813). "Cursory Remarks on Corpulency", 2nd ed., p. 3. Callow, London.

Weiss, S., and Minot, G. R. (1933). "Nutrition in Relation to Arteriosclerosis", in "Arteriosclerosis", ed. E. V. Cowdry, chap. 8, p. 233. (Josiah Macy, Jr. Foundation). Macmillan, New York.

Wilens, S. L. (1947). Arch. intern. Med., 79, 129. 